\title{
Learning Model on Islamic Religious Education in Improving Student Motivation Andachievement
}

\author{
Sampara Lili ${ }^{1 *}$, Ana Cahyani Fatima ${ }^{2}$ \\ ${ }^{1,2}$ STIT Sunan Giri, Bima, Nusa Tenggara Barat, Indonesia \\ email:1*syampara2511@gmail.com;'2anacahayani@gmail.com
}

\begin{abstract}
This study aims to assess the shape and Effectiveness of Active Learning model implementation in the field of Islamic religious education studies in improving student achievement motivation and Islamic Elementary School fifth grade Athirah Makassar. This study is a class action (Classroom Action Research) with the kind of collaborative. This research phase follows the model developed by Kemmis and Taggart, namely in the form of a spiral cycleincludes planning, implementation, observation, and reflection. Technique-data collection techniques used are: (1) observation; (2) interview; (3) documentation, and (4) achievement test. Based on the research that has been conducted argued that the application of active learning can increase learning motivation and achievement of students in class V (Al-Mu'min) Islamic Primary School Athirah Makassar on fieldIslamic religious education studies. From the data in the field shows that there is increased motivation of learners whothe original value of the average pre-cycle increased to 69.13 or 63.56 increased by about $5.57 \%$ in the first cycle, the second cycle increased to 80.41 or about $16.84 \%$. And in Cycle III are improved Becoming $91.55 \%$ or approximately $27.96 \%$. With the increased motivation of learners, then their learning achievement also increased, which had an average value of 63.56 pre-cycle increased to 69.13 or about $5.75 \%$ in the first cycle, the second cycle increased to 81 , an increase of approximately $17.44 \%$, and in cycle III are improved Becoming $84.63 \%$ or approximately $21.7 \%$ of the pre-cycle to the third cycle. Active Learners research Based on the results it was concluded that very effective in increasing motivation and learning achievement of students in the field of Islamic religious education studies.
\end{abstract}

\section{Keywords-Active Learning, Motivation and Achievement Student}

\section{INTRODUCTION}

Education for human life is an absolute requirement that must be met throughout life. Education altogether impossible without a group of people can thrive in line with the aspirations (ideals) for advanced, prosperous and happy.Education is also a path or way which leads man to achieve his goal.

IJoASER,Volume 2,Issue 3, November,2019

DOI: 10.33648/ijoaser.v2i2.39

Copyriht: STAI Al-Furqan Makassar,Indonesia

Content License: CC-BY-SA 
Education is an attempt to conscious and deliberate to create an atmosphere of learning and the learning process so that learners are actively developing the potential for him to have the spiritual power of religion, self-control, personality, intelligence, noble morality, as well as the skills needed him, society, nation and state [1].

In Law No. 20 of 2003 on the national education system is also mentioned that:

"Education is a conscious and deliberate effort to create an atmosphere of learning and the learning process so that learners are actively developing the potential for him to have the spiritual power of religion, self-control, personality, intelligence, noble character, and skills needed him, society, nation and state" [2],

Islamic Education, as one vehicle that can affect the growth and development potential of learners the way of life provided by the creator, and the students themselves who will choose and decide and develop a way of life and the lives that have been studied and chosen. Function educators in Islamic Education is attempting to select, specify and develop teaching methods that allow to help ease, speed, customs, and the pleasure of learners to study Islam and used as guidelines and instructions of life and his life [3]. Nowadays, the role of teachers as facilitators lead where students is central to learning. One model of learning that can support these conditions is the Active Learning. Husamah And Yanur Setyaningrum, in his book DesignBased Learning Achievement Kompotemsi said that:

"Active Learning is a source of unity a comprehensive set of learning strategies. Active learning includes a variety of ways to make students active from the beginning through activities that build teamwork and in a short time to make them think about the subject matter [4]

The success of the students in the learning process can be measured the extent to which the students can master the learning materials discussed, generally referred to with academic achievement. One effort to increase student achievement and learning motivation is that teachers can choose appropriate learning strategies in terms of teaching methods, classroom situations, the ability of students in general and in considering the time available and so forth.

Athirah is one of the largest Islamic school in southern Sulawesi, Islam Athirah terdidri school from kindergarten, elementary, middle, and high school. Athirah Islamic school had Competitive Program 1. Tahzin, Tahfidz, and tadabbur al-Qur, an. 2. The cultural mission to Europe and the Middle East. 3. The exchange student to Australia. 4. Language Skills. 5. Leadership. 6. Parents day. 7. Science and social Fair. 8. Drama. Fieldtrip 9. 11. 10. Observation Village kejepang Scholarship. 12. Scholarships to China. And 13. A scholarship to the University of Turkey that there are some 
countries [5].In addition Athirah also famous achievements of learners who excel to the national level. However, with time Athirah Makassar Islamic schools should improve quality in order to maintain the achievements of which the quality of learning. Based on the above background, the researchers will conduct research with the title "Implementation of active learning model in the field of study of Islamic religious education in improving student achievement motivation and SD Islam Athirah Makassar.

\section{METHOD}

The method used in this research is the Classroom action research or action research (PTK). The research is classroom action research (Classroom Action Research), action research is a form of scrutiny on an action learning activities, which deliberately raised and occur within a class simultaneously. Such measures are given by the teacher or the guidance of the teachers who doby learners [6]. PTK is the action research conducted with the aim of improving the quality of classroom teaching practice [7].

\section{A. Object of research}

The location of this research is the Islamic Primary School Athirah Makassar. The reason for choosing this location was the researchers know that the SD Islam Athirah Makassar is one of the top schools are equipped with facilities and infrastructure so the methodology of teachers in teaching can be varied by the use of various media in the learning process than that researchers interested in researching in SD Islam Athirah Makassar because it is one of the many schools that graduate students continue their studies out negeri.Penetapan location of this research is based on the consideration that similar studies have not been done on how the implementation of the Active learning model in the field of study PAI in improving motivation and learning achievement Elementary school fifth grade students.

\section{B. Research subject}

The subjects were students of class V. al-Mu'min Islamic Primary School Athirah Makassar totaling 32 students consisting of 18 male students and 14 female students.

\section{Data analysis method}

IJoASER,Volume 2,Issue 3, November,2019

DOI: 10.33648/ijoaser.v2i2.39

Copyriht: STAI Al-Furqan Makassar,Indonesia

Content License: CC-BY-SA 
The data analysis method is an effort to find and organize systematically record the results of observations, interviews, and more to improve pemahamanpeneliti of the cases studied and presented them as for lain.Data findings were analyzed using quantitative and qualitative analysis techniques. For quantitative analysis used descriptive statistics are average and percentage, frequency tables, the percentage of the highest and lowest values. To analyze the success rate or the percentage of student success after each revolution the learning process carried out by conducting an evaluation form about the written test. Once the data is collected, it needs to be processed in accordance with its properties.

$$
\mathrm{P}=\frac{f}{N} x 100 \%
$$

Information :

$\mathrm{f}$ : frequency being searched percentage.

$\mathrm{N}$ : Number of Case (Number of frequency / number of people)

P: Mean (average) were searched.

$$
\mathrm{mx}=\frac{\Sigma f x}{N}
$$

Information:

$\Sigma$ fx: The amount by multiplying the frequency with values obtained.

$\mathrm{N} \quad$ : Number of cases (Number of frequency / number of people)

$\mathrm{mx} \quad$ : mean (Average) were searched [8].

Based on the exposure of researchers use quantitative and qualitative analysis techniques in the study to determine the effectiveness of Active Learning Implementation Model In the field of Islamic Religious Education Studies in improving student learning motivation in SD Islam Athirah Makassar.

\section{RESULTS AND DISCUSSION}

\section{A. An Overview of Research Sites}

Since in 1984, building Islamic schools Athirah stood firm. From kindergarten through high school. The school building was inaugurated exactly on 24 April 1984 and commenced operations earlier in the year 19851986 study. A piece of land with an area of $12141 \mathrm{~m} 2$ in the street Kajaolaliddo number 22 Makassar which was oriented to a hotel establishment, the establishment of schools ini.Menilik switch to its history, this school stems from the strong desire of the figure of Mr. Hadji Kalla and his wife, Mrs. Hadjah Athirah to play an active role in promoting education. He was caring and had a high commitment. Implementation is also presented through its business group pioneered a foundation. His name, Welfare and Education Foundation Islam Hadji Kalla as CSR program on September 9, 
1981. Under the foundation that built the formal school with the name of the Islamic Educational Athirah.

B. Active Learning model implementation in the field of study of Islamic religious education in increasing motivation and learning achievement of Grade V SD Islam Athirah Makassar

Pre cycle was held on Thursday, February 20, 2014, researchers observed that teachers apply methods in the learning process. PAI teachers do not use the division or the formation of groups. On the implementation cycle Pre conveyed material is Faith To the Apostle of Allah. Having conducted a repeat or end the test of learning from the class average value of $75.53 \%$ with the number of learners who completed $56.25 \%$ or 18 students. and who did not complete as much as $43.75 \%$ or 14 students. This means there are still a class $\mathrm{V}$ learners have not been able to complete the evaluation of the well. So also with the activities of learners in class $\mathrm{V}$ (al'Mu'min) which is still $67.96 \%$ who pay attention to teacher explanation well, $66.40 \%$ dared to ask the Guru, $63.28 \%$, which took the initiative to elaborate on the topic of discussion, $64,84 \%$ of students who are enthusiastic in learning activities, $57.03 \%$ of people active and contribute to the discussion, and $68.84 \%$ were diligent and independent tasks [9].

\section{C. first cycle}

I cycle research conducted on Thursday, February 27, 2014. Learning was held for $3 \times 35$ minutes. Implementation of learning in the first cycle was conducted by collaborators Mr. Jamaluddin Mukhlis, S.Ag. M.Pd.I. as a teacher of Islamic religious education and was accompanied by the researcher. The initial process of learning at the first meeting begins, By opening beberpa learning with a series of activities. At the core activities of the learning process continued with the application of active learning. The teacher divides participants didikmenjadi eight groups, each group consisting of four learners. Each group carry out the assignment of teachers to study the learning materials. Based on observations and penberian tests that have been carried out there was little increase motivation and learning achievements of learners [10].

D. cycle II

IJoASER,Volume 2,Issue 3, November,2019

DOI: 10.33648/ijoaser.v2i2.39

Copyriht: STAI Al-Furqan Makassar,Indonesia

Content License: CC-BY-SA 
The results of the first cycle studies show that research objectives have not been achieved and should be continued in the second cycle. Things are not perfectly implemented in the first cycle improved in the second cycle. Implementation of the second cycle was held on Thursday, March 6th, 2014 Learning was held for 3 x 35 minutes.Based on observations that have been implemented are increased motivation and student achievement however, there are still students who have not reached the target [11].

\section{E. Cycle III}

The results of the second cycle studies show that research objectives have not been achieved $100 \%$ due to still unresolved learners study results and should be continued in the third cycle. Things are not perfectly implemented in the second cycle improved in the third cycle. Implementation of the third cycle was held on Thursday, March 13, 2014. Learning was held for $3 \times 35$ minutes. Based on the observation that has dilaksanakanPada this cycle all the students who attend classes obtain excellent results in which all students completed their study results [12].

Based on observations and the provision of tests that have been carried out there is a significant improvement on learning motivation and achievement of learners from pre-Cycle, Cycle I, Cycle II and Cycle III.

\section{F.Effectiveness of Active Learning model implementation in the field of study of Islamic religious education in increasing motivation and learning achievement of Grade V SD Islam Athirah Makassar}

Based on observations activity of students in class V (Al-Mu'min) SD Islam Athirah Makassar overall during the learning obtained the following data: 1) In the pre-cycle (Thursday, 20 February 2014) the percentage of the activity of learners $63,56 \%$, so it can be said that many learners who perform activities in the learning process berkriteria well. 2) In the first cycle (Thursday, 27 February 2014) the percentage of learners' activity is $69.13 \%$, so it can be said that many learners who conduct activities in the learning process berkriteria well. 3) In the second cycle (Thursday, March 6, 2014) the percentage of learners' activity is $80.41 \%$, so it can be said that many learners who conduct activities in the learning process berkriteria well. 
From the above data, then visualized in the form of the histogram as shown in Figure 1 below

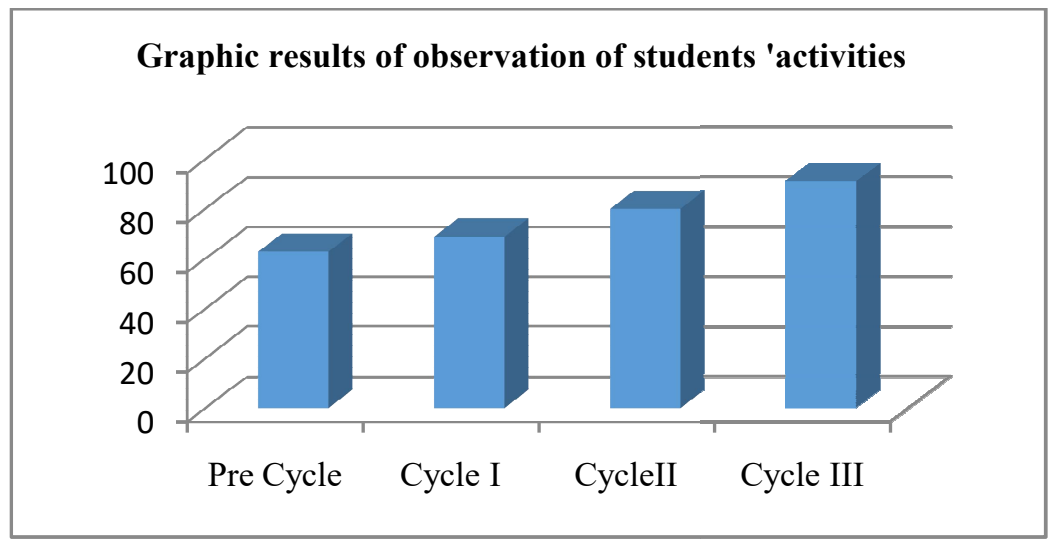

While the learning achievements of learners, the average value obtained difference learning tests at each end of the cycle. The average test learning each cycle obtained the following data: 1) Resultspre-cycle test (Thursday, February 20, 2014) the average value of the test was $75.53 \%$ with a percentage of $56.25 \%$ (18 Learners) were completed and 43.75\% (14 children) were not completed. 2) The test results In the first cycle (February 27 th 2014 ) the average value of the test is $76.25 \%$. With a percentage of $56.25 \%$ (32 participants didk the complete and 43\% (14 Learners) were not completed. 3). The test results In the second cycle (March 6, 2014) the average value of the test is $81 \%$. by percentage, $93.33 \%$ (28 learners) were completed and 6,67\% (2 children) were not completed. 4) The test results In the third cycle (March 13th 2014) the average value of the test is $84.63 \%$. by percentage, $100 \%$ (30 learners) are completely and $0 \%$ of learners who do not tuntas.Dari the above data and then visualized in the form of the histogram as shown in figure 2 and figure 3 below. 


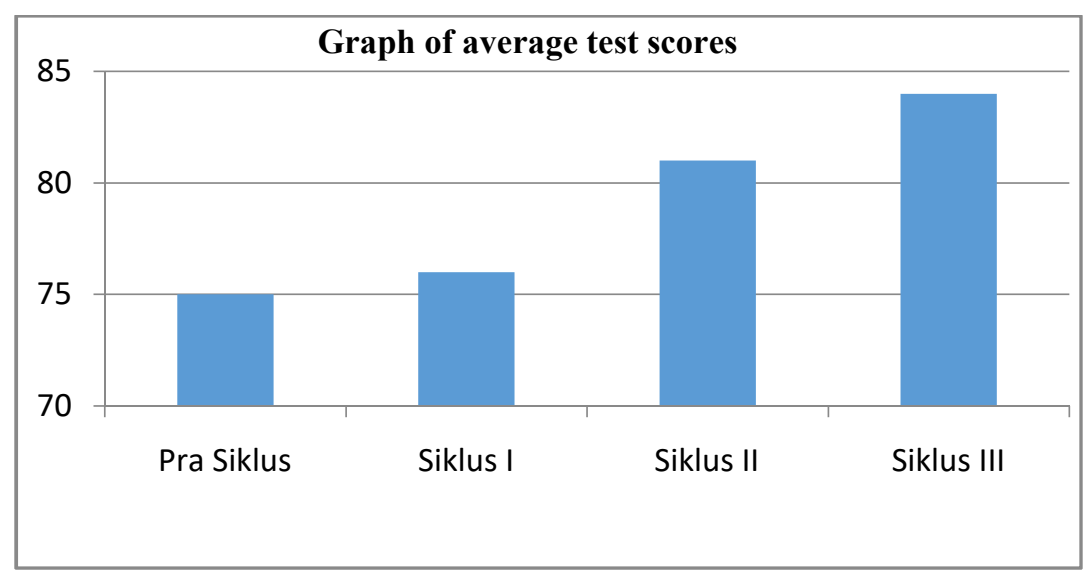

Figure 2. Histogram Results End Cycle Test Scores

\section{CONCLUSION}

Based on the research that has been done shows Implemtasi form Active Learning Model In the field of study PAI.firstform study groups, the second step each group carry out tasks assigned by the teacher. While the teacher's task in this study is giving a boost on the benefits of lessons learned, especially in the passive group, motivate learners to be more willing to express their ideas. Implemntasi Model Active learning is very effective in increasing motivation and student achievement in the subject of Islamic Elementary PAI in Makassar Athirah by applying the principles or components consistently active learning.

\section{REFERENCES}

[1] Law No. 20 of 2003, On the National Education System (Education), Chapter I Article 1 Paragraph 1 (Bandung: Image Umbara, 2003), p. 72.

[2] Editorial Team Focus Media, the Association of Legislation About the National Education System (Bandung: Focus Media, 2006), p.

[3] Muhaimin, Islamic Education Paradigm: Making Efforts Islamic Education in Schools, (Bandung: PT Young Rosdakarya, 2004), Cet. 3, p. 184

[4] Husamah And Yanur Setyaningrum, Design-Based Learning Achievement Kompotemsi, (Cet; 1: Jakarta: Achievements Pustakaria, 2013), h. 165

[5] Athirah Magazine Event Champion National Drama Festival, Athirah Exist in Europe, (IX Edition of March, 2014)

[6] Suharsimi Arikunto, Research Procedure A Practical Approach, (Jakarta: Rineka Copyright, 2006), p. 90

[7] Kunandar, Class Action Research Easy Steps For Teacher Professional Development (Cet.V; Jakarta: King Grafindo 2010), h.45 
[8] Anas Sudijono, Introduction to Education Statistics, (Cet, 2; Jakarta: Rajawali Press: 2010), p. 43

[9] Student Class 5 (Al-Mu'mi n), Implementation of Active Learning Model, in SD Islam Athirah Makassar, observations and test results, on Thursday, 20th February, 2014.

[10] Student Class 5 (Al-Mu'mi n), Implementation of Active Learning Model, in SD Islam Athirah Makassar, observations and test results, on Thursday, February 27, 2014.

[11] Student Class 5 (Al-Mu'mi n), Implementation of Active Learning Model, in SD Islam Athirah Makassar, observations and test results, on Thursday, March 6, 2014.

[12] Student Class 5 (Al-Mu'mi n), Implementation of Active Learning Model, in SD Islam Athirah Makassar, observations and test results, on Thursday, March 6, 2014. 